\title{
Plasminogen activator inhibitor-1 (PAI-1) gene 4G/5G promoter polymorphism is not associated with breast cancer ${ }^{\star}$
}

\author{
Janusz Błasiak ${ }^{\bowtie}$ and Beata Smolarz \\ Department of Molecular Genetics, University of Łódż, St. Banacha 12/16, 90-237 Łódż, Poland
}

Received: 20 December, 1999

Key words: plasminogen activator inhibitor-1 (PAI-1), PAI-1 gene, gene polymorphism, breast cancer, prognostic marker

\begin{abstract}
The antigen content of plasminogen activator inhibitor-1 (PAI-1) in primary breast cancer tissue extracts may be of strong prognostic value: high levels of PAI-1 in tumors predict poor prognosis for patients. The gene encoding PAI-1 is highly polymorphic and an insertion (5G)/deletion (4G) polymorphism in the PAI-1 gene promoter (the 4G/5G polymorphism), may have functional significance in PAI-1 expression. In the present work the distribution of genotypes and frequency of alleles of the $4 \mathrm{G} / 5 \mathrm{G}$ polymorphism in subjects with breast cancer were investigated. Tumor tissues were obtained from 100 postmenopausal women with node-negative and node-positive ductal breast carcinoma with uniform tumor size. Blood samples from age matched healthy women served as control. The 4G/5G polymorphism was determined by PCR amplification using the allele specific primers. The distribution of the genotypes of the 4G/5G polymorphism in both control and patients did not differ significantly ( $P$ ) 0.05) from those predicted by the Hardy-Weinberg distribution. There were no differences in the genotype distributions and allele frequencies between node-positive and node-negative patients. The $4 \mathrm{G} / 5 \mathrm{G}$ polymorphism may not be linked with elevated level of PAI-1 observed in breast cancer and therefore may not be associated with appearance and/or progression of breast cancer.
\end{abstract}

Cancer progression, leading to its invasion and eventually to metastasis, is a multifactorial process that includes adherence to the basement membrane, secretion of proteolytic enzymes and cancer cell migration into vessels and lymphatic nodes followed by extravasation at distant sites [1]. A critical step of the progression is crossing tissue boundaries by the malignant cells which distinguishes proliferative disorders and carci-

\footnotetext{
${ }^{\star}$ This work was supported by grant 6 P04A 02016 from the State Committee for Scientific Research (KBN, Poland) to B. Smolarz.

${ }^{\bowtie}$ Send all correspondence to Janusz Błasiak, fax (48 42) 635 4484; e-mail januszb@biol.uni.lodz.pl Abbreviations: PAI-1, plasminogen activator inhibitor-1; ECM, extracellular matrix; uPA, urokinase type plasminogen activator; tPA, tissue type plasminogen activator; uPAR, urokinase receptor.
} 
noma in situ from true malignancy [2]. Two main boundaries are basement membrane and extracellular matrix (ECM) and their breakdown facilitates cancer cells invasion into the surrounding normal tissues [3]. This process is mediated by serine proteinases and metalloproteinases [4]. The plasminogen activation system contains proteolytic factors that, released by cancer cells, can degrade ECM and promote tumor invasion and metastasis [5]. The system includes the urokinase type plasminogen activator ( $\mathrm{uPA}$ ), the tissue type plasminogen activator ( $\mathrm{tPA}$ ), the specific plasminogen activator inhibitors PAI-1 and PAI-2 and the urokinase receptor (uPAR). PAI-1, an approximately $50 \mathrm{kDa}$ glycoprotein belonging to the serine proteinase inhibitor superfamily, is the major physiological inhibitor of the system.

About two third of all breast cancer patients is node-positive and in general receives the adjuvant therapy, the other one third, which is node-negative, may receive or not such therapy depending on the chance of disease recurrence [6]. It is therefore important to identify high-risk node-negative breast cancer patients in order to fight the disease and avoid unnecessary chemotherapy in low-risk patients. Prognostic factors commonly used to such identification are tumor size, nuclear grade, steroid hormone receptor status [7].

PAI-1 was shown first to be a prognostic marker in both node-negative and node-positive breast cancers [8-11]. The elevated level of PAI-1 can be associated with shorter recurrence-free survival and shorter overall survival. Changes in PAI-1 biosynthesis are usually proceeded by changes in its gene transcription and mRNA level [12, 13]. Gene variability could contribute to the level of the PAI-1 biosynthesis [14]. Nine different polymorphisms of the PAI-1 gene have been described: two $(\mathrm{CA})_{\mathrm{n}}$ repeat polymorphisms, one in the promoter and one in the intron 4 [15, 16]; an HindIII restriction fragment length polymorphism [17]; an insertion (5G)/deletion (4G) polymorphism at posi- tion -675 of the PAI-1 gene promoter [18]; two $\mathrm{G} \rightarrow$ A substitutions at positions -844 and +9785 ; three polymorphisms in the $3^{\prime}$ untranslated region: $\mathrm{T} \rightarrow \mathrm{G}$ substitution at position +11053 and 9-nucleotide insertion/deletion located between nucleotides +11320 and +11345 in a threefold repeated sequence [14] and $\mathrm{G} \rightarrow \mathrm{A}$ substitution in position +12078 [19]. In view of the potential significant role of PAI-1 for tumor spreading, it is important to know, whether these polymorphisms can account for the development and/or progression of breast cancer.

Among the variants of the PAI-1 gene an insertion (5G)/deletion (4G) polymorphism (the $4 \mathrm{G} / 5 \mathrm{G}$ polymorphism) was most frequently studied. Its location at the promoter of the gene indicated its possible role in the regulation of the transcription of the PAI-1 gene. It was shown that particular genotypes of this polymorphism could be associated with cerebral sinus thrombosis [20], coronary arterial disease [21, 22] and other vascular disturbances but little is known on possible role of the $4 \mathrm{G} / 5 \mathrm{G}$ polymorphism in cancer. In our preliminary study we showed that this polymorphism might have been linked with an appearance of various types of cancer [23].

In the present work the distribution of genotypes and frequency of alleles of the $4 \mathrm{G} / 5 \mathrm{G}$ polymorphism in women with node-negative and node-positive breast cancer was investigated.

\section{MATERIALS AND METHODS}

Breast cancer samples. Tumor tissues were obtained from 100 postmenopausal women with node-negative $(\mathrm{n}=39)$ and node-positive ( $\mathrm{n}=61$ ) ductal breast carcinoma treated at the Department of Gynaecological Oncology, Medical University of Łódź, between 1993 and 1997. No distant metastases were found in patients at the time of treatment. The patients ranged in age from 40 to 82 years (median age 58 years). Median fol- 
low-up of patients still alive at the time of analysis was 39 months (range: 2-71 months). The average tumor size was $20 \mathrm{~mm}$ (range 17-32 mm). All tumors were graded by a method based on the criteria of Scarff-Bloom-Richardson [24, 25]. There were 20 tumors of I grade, 45 of II grade and 35 of III grade in total. In node-negative patients these numbers were: I - 9, II - 16, III - 14; in node-positive: I - 11, II - 29, III - 21. Steroid receptors status was not determined in the investigated group. Blood samples from age matched healthy women $(n=106)$ served as control.

The breast cancer tissue samples were fixed routinely in formalin and embedded in paraffin. Archival paraffin-embedded tumor sections on slides were deparaffinized in xylene and rehydrated in ethanol and distilled water. DNA was extracted using commercially available QIAmp Kit (Qiagen GmbH, Hilden, Germany) DNA purification kit according to manufacturer's instruction. Blood was mixed with equal volume of a buffer containing $1 \%$ Triton X-100, 2\% sarcosyl, 0.8 M urea, 20 mM EDTA, $0.4 \mathrm{M} \mathrm{NaCl}, 200 \mathrm{mM}$ Tris, $\mathrm{pH}$ 8.0, and RNase A was added to a final concentration of 100 $\mu \mathrm{g} / \mathrm{ml}$. Following $2 \mathrm{~h}$ incubation at $55^{\circ} \mathrm{C}$ proteinase $\mathrm{K}$ was added to a final concentration of $125 \mu \mathrm{g} / \mathrm{ml}$ and incubation continued for additional $2 \mathrm{~h}$, then DNA was extracted one with phenol and twice with chloroform.

Determination of PAI-1 genotype. PAI-1 4G/5G promoter genotype was established for each subject by polymerase chain reaction

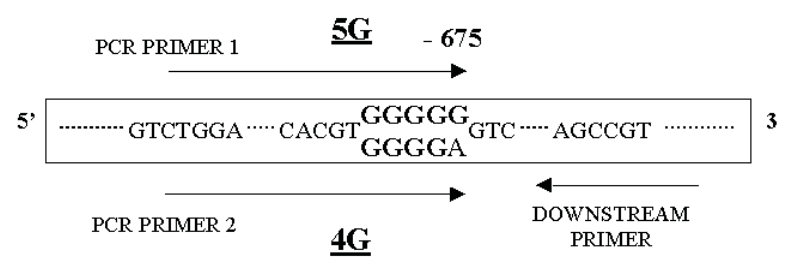

Figure 1. PAI-1 promoter sequences comprising the region of the $4 \mathrm{G} / 5 \mathrm{G}$ polymorphism.

(PCR) amplification of genomic DNA using the allele specific primers (Fig. 1): insertion
5G allele: 5'-GTC TGG ACA CGT GGG GG-3', deletion 4G allele: $5^{\prime}$-GTC TGG ACA CGT GGG GA-3' each in a separate PCR reaction together with the common downstream primer 5'-TGC AGC CAG CCA CGT GAT TGT CTA G-3' and a control upstream primer 5 '-AAG CTT TTA CCA TGG TAA CCC CTG GT-3' to verify the occurrence of DNA amplification in the absence of the allele on the genomic DNA [26]. The PCR was carried out in a MJ Research, INC thermal cycler, model PTC-150-162-25 in a final volume of $25 \mu \mathrm{l}$ containing $10 \mathrm{ng}$ DNA, 13 pmol of specific primers, $1 \mathrm{mM}$ dNTPs and $1 \mathrm{U}$ Taq polymerase together with $2.5 \mu \mathrm{l}$ of $10 \times$ Taq buffer. The PCR cycle conditions were $94^{\circ} \mathrm{C}$ for $60 \mathrm{~s}, 54^{\circ} \mathrm{C}$ for $30 \mathrm{~s}$ then $72^{\circ} \mathrm{C}$ for $40 \mathrm{~s}$, repeated for $35 \mathrm{cy}$ cles. The amplified DNA fragments were separated by a $5 \%$ polyacrylamide gel electrophoresis and, after staining with ethidium bromide, viewed under ultraviolet light. Each subject was classified into one of the three possible genotypes: $4 \mathrm{G} / 4 \mathrm{G}, 4 \mathrm{G} / 5 \mathrm{G}$ or $5 \mathrm{G} / 5 \mathrm{G}$.

Statistical analysis. The allelic frequencies were estimated by gene counting and genotypes were scored. The observed numbers of each PAI-1 genotype were compared with that expected for a population in Hardy-Weinberg equilibrium by using a $\chi^{2}$ test. The significance of the differences of observed alleles and genotypes between groups was tested using the $\chi^{2}$ analysis.

\section{RESULTS}

From the PCR analysis, all the patients and controls were divided into three genotypes of the PAI-1 gene promoter region: $4 \mathrm{G} / 4 \mathrm{G}$, $4 \mathrm{G} / 5 \mathrm{G}$ and $5 \mathrm{G} / 5 \mathrm{G}$ (Fig. 2). Table 1 shows genotype distribution between breast cancer patients and controls. Both distributions did not differ significantly $(P>0.05)$ from those predicted by the Hardy-Weinberg distribution. Additionally, there were no differences in the frequencies of the $4 \mathrm{G}$ and $5 \mathrm{G}$ alleles between patients and controls. 
Distributions of the $4 \mathrm{G} / 5 \mathrm{G}$ genotypes as well as the frequencies of the $4 \mathrm{G}$ and $5 \mathrm{G}$ alleles for node-positive and node-negative signed to histological grades and the distribution predicted by Hardy-Weinberg equilibrium $(P>0.05)$. The were no differences in fre-

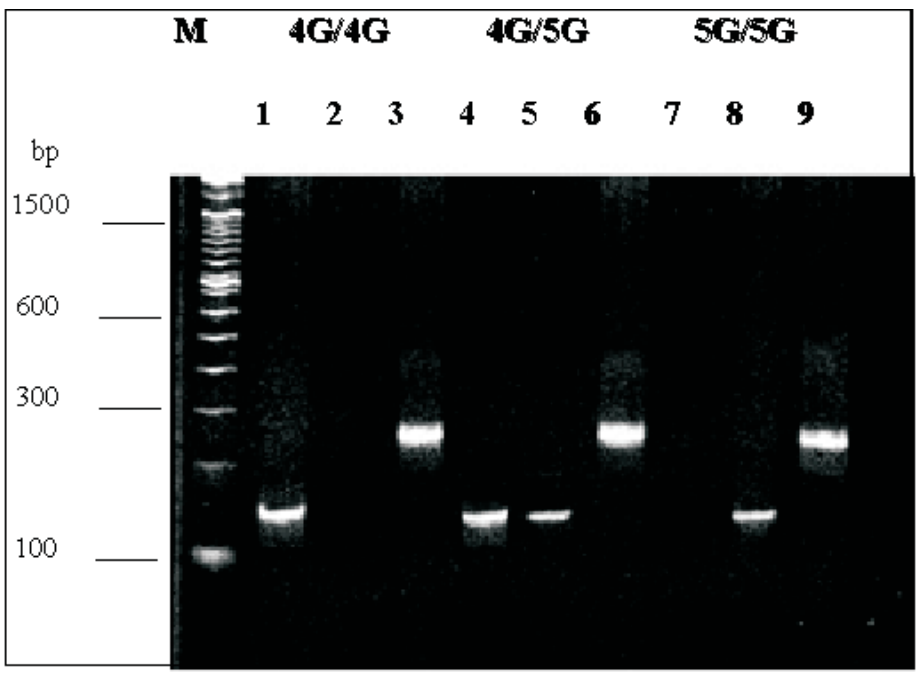

Figure 2. A typical result of allele specific polymerase chain reaction performed with a fragment of the PAI-1 gene promoter and analysed by a $5 \%$ polyacrylamide gel electrophoresis, staining with ethidium bromide and viewed under ultraviolet light.

Lanes 1, 4 and 7 display the product of amplification with a primer specific to the $5 \mathrm{G}$ allele; lanes 2, 5 and 8 - the $4 \mathrm{G}$ allele, and lanes 3, 6 and 9 - controls. DNA of each genotype was prepared from the same donor. M denotes $100 \mathrm{bp}$ DNA ladder marker.

breast cancer patients are displayed in Table 2. It can be seen from the Table that there were no significant differences between these two groups in both genotype distribution and allele frequencies $(P>0.05)$.

Dependencies of the distribution of genotypes and frequencies of alleles on the tumor grade evaluated according to Scarf-BloomRichardson criteria in patients with node-positive and node-negative breast cancer are displayed in Table 3 and 4, respectively. There were no significant differences between distributions of genotypes in subgroups as- quencies of the $4 \mathrm{G}$ and $5 \mathrm{G}$ alleles between subgroups either $(P>0.05)$.

\section{DISCUSSION}

The 4G/5G polymorphism may be related to differential binding of proteins that influence its transcription [21]. Such connection between genotype and phenotype has been reported in vascular disease, but little is known about possible role of the $4 \mathrm{G} / 5 \mathrm{G}$ polymorphism in cancer. In light of substantial evi-

Table 1. Distribution of 4G/5G genotypes and frequencies of the 4G and 5G alleles in patients with breast cancer and controls

\begin{tabular}{|c|c|c|c|c|}
\hline & \multicolumn{2}{|c|}{ Breast cancer patients $(n=100)$} & \multicolumn{2}{|c|}{ Controls $(\mathrm{n}=106)$} \\
\hline & Number & Frequency & Number & Frequency \\
\hline 4G/4G genotype & 31 & 0.31 & 21 & 0.20 \\
\hline 4G/5G genotype & 40 & 0.40 & 48 & 0.45 \\
\hline 5G/5G genotype & 29 & 0.29 & 37 & 0.35 \\
\hline$\chi^{2}$ & \multicolumn{2}{|c|}{$3.987^{\mathrm{a}}$} & \multicolumn{2}{|c|}{$0.591^{\mathrm{a}}$} \\
\hline $4 \mathrm{G}$ allele & 102 & $0.51^{b}$ & 90 & 0.42 \\
\hline $5 \mathrm{G}$ allele & 98 & $0.49^{\mathrm{b}}$ & 122 & 0.58 \\
\hline
\end{tabular}


dence that the progression of breast cancer can be associated with elevated levels of PAI-1, it seems reasonable to check a possible
It should be taken into account that in addition to genotype, a series of environmental factors affects plasma PAI-1 levels. PAI-1 syn-

Table 2. Distribution of 4G/5G genotypes and frequencies of the $4 \mathrm{G}$ and $5 \mathrm{G}$ alleles in patients with node-positive and node-negative breast cancer

\begin{tabular}{lllll}
\hline & \multicolumn{2}{c}{ Node-positive $\begin{array}{c}\text { breast cancer patients } \\
(\mathrm{n}=61)\end{array}$} & \multicolumn{2}{c}{$\begin{array}{c}\text { Node-negative breast cancer patients } \\
(\mathrm{n}=39)\end{array}$} \\
& Number & Frequency & Number & Frequency \\
\hline 4G/4G genotype & 17 & 0.28 & 14 & 0.36 \\
$4 \mathrm{G} / 5 \mathrm{G}$ genotype & 24 & 0.39 & 16 & 0.41 \\
$5 \mathrm{G} / 5 \mathrm{G}$ genotype & 20 & 0.33 & 9 & 0.23 \\
$\chi^{2}$ & & & & \\
$4 \mathrm{G}$ allele & $2.732^{\mathrm{a}}$ & & & 1.070 \\
$5 \mathrm{G}$ allele & 58 & $0.48^{\mathrm{a}}$ & 44 & 0.56 \\
\hline
\end{tabular}

${ }^{\mathrm{a}} P>0.05$ as compared with node-negative patients

correlation between the polymorphism and clinical status of breast cancer patients. In this work conducted on 100 ductal breast carcinoma patients we did not find any correla- thesis has been related to high blood levels of glucose, insulin and triglycerides [27, 29], sex hormone [30] and angiotensin IV [31]. Increased level of PAI-1 can be also linked with

Table 3. Dependency of the distribution of 4G/5G genotypes and frequencies of the $4 \mathrm{G}$ and $5 \mathrm{G}$ alleles on the tumor grade in patients with node-positive breast cancer ${ }^{\text {a }}$

\begin{tabular}{|c|c|c|c|c|c|c|}
\hline \multirow[t]{2}{*}{ Grade $^{b}$} & \multicolumn{2}{|c|}{$\mathrm{I}(\mathrm{n}=11)$} & \multicolumn{2}{|c|}{ II $(n=29)$} & \multicolumn{2}{|c|}{ III $(\mathrm{n}=21)$} \\
\hline & Number & Frequency & Number & Frequency & Number & Frequency \\
\hline 4G/4G genotype & 3 & 0.27 & 9 & 0.31 & 3 & 0.14 \\
\hline 4G/5G genotype & 5 & 0.46 & 12 & 0.41 & 9 & 0.43 \\
\hline 5G/5G genotype & 3 & 0.27 & 8 & 0.28 & 9 & 0.43 \\
\hline$\chi^{2}$ & \multicolumn{2}{|c|}{$0.089^{c}$} & \multicolumn{2}{|c|}{$0.852^{\mathrm{c}}$} & \multicolumn{2}{|c|}{$0.085^{\mathrm{c}}$} \\
\hline $4 \mathrm{G}$ allele & 11 & 0.50 & 30 & 0.52 & 15 & 0.36 \\
\hline $5 \mathrm{G}$ allele & 11 & 0.50 & 28 & 0.48 & 27 & 0.64 \\
\hline
\end{tabular}

${ }^{\mathrm{a}} \mathrm{n}=61 ;{ }^{\mathrm{b}}$ according to Scarf-Bloom-Richardson criteria; ${ }^{\mathrm{c}} P>0.05$ as compared with Hardy-Weinberg distribution

tion between $4 \mathrm{G} / 5 \mathrm{G}$ genotypes and occurrence of cancer. Moreover, we did not detect any significant difference between genotypes of node-positive and node-negative patient, that suggests a lack of association between $4 \mathrm{G} / 5 \mathrm{G}$ genotype and breast cancer invasiveness. smoking habits [32], alcohol consumption [33] and acute infections [34].

Clinical studies have shown the association between 4G/5G polymorphism and plasma PAI-1 activity, the $4 \mathrm{G}$ allele being associated with higher levels of PAI-1, in young healthy controls and young myocardial infarction pa- 
tients from Sweden [27] and in the larger French and Irish population of myocardial infarction patients and healthy controls of the fluence the transcription of the gene through the regulation by cytokines released by tumor cells but so far no such effect has been shown.

Table 4. Dependency of the distribution of 4G/5G genotypes and frequencies of the $4 \mathrm{G}$ and $5 \mathrm{G}$ alleles on the tumor grade in patients with node-negative breast cancer ${ }^{a}$

\begin{tabular}{|c|c|c|c|c|c|c|}
\hline \multirow[t]{2}{*}{ Grade $^{b}$} & \multicolumn{2}{|c|}{$\mathrm{I}(\mathrm{n}=9)$} & \multicolumn{2}{|c|}{$\mathrm{II}(\mathrm{n}=16)$} & \multicolumn{2}{|c|}{ III $(\mathrm{n}=14)$} \\
\hline & Number & Frequency & Number & Frequency & Number & Frequency \\
\hline 4G/4G genotype & 2 & 0.22 & 4 & 0.25 & 7 & 0.50 \\
\hline 4G/5G genotype & 5 & 0.55 & 7 & 0.43 & 5 & 0.35 \\
\hline 5G/5G genotype & 2 & 0.22 & 5 & 0.32 & 2 & 0.15 \\
\hline$\chi^{2}$ & \multicolumn{2}{|c|}{$0.104^{\mathrm{c}}$} & \multicolumn{2}{|c|}{$0.238^{\mathrm{c}}$} & \multicolumn{2}{|c|}{$0.465^{\mathrm{c}}$} \\
\hline $4 \mathrm{G}$ allele & 9 & 0.50 & 15 & 0.47 & 19 & 0.68 \\
\hline $5 \mathrm{G}$ allele & 9 & 0.50 & 17 & 0.53 & 9 & 0.32 \\
\hline
\end{tabular}

${ }^{\mathrm{a}} \mathrm{n}=39 ;{ }^{\mathrm{b}}$ according to Scarf-Bloom-Richardson criteria; ${ }^{\mathrm{c}} \mathrm{P}>0.05$ as compared with Hardy-Weinberg distribution

ECTIM study [35]. Such association has been recently shown for large Italian [36] and Japanese [22] populations.

Despite many results suggesting an importance of the $4 \mathrm{G} / 5 \mathrm{G}$ polymorphism in vascular diseases and prevalence of the $4 \mathrm{G} / 4 \mathrm{G}$ genotype in these conditions, some reports suggest that the distributions of the $4 \mathrm{G} / 5 \mathrm{G}$ genotypes among men who developed myocardial infarction or venous thromboembolism were virtually identical to those free of vascular diseases, and that relative risk of future thrombosis among those with the $4 \mathrm{G} / 4 \mathrm{G}$ genotype compared with those with $4 \mathrm{G} / 5 \mathrm{G}$ or $5 \mathrm{G} / 5 \mathrm{G}$ genotype was just 1.02 [37]. It is worth noting that this study was conducted in a large cohort (almost 15000) and there was no modification in the effect as a result of age, smoking, family history of vascular diseases and drug use. It was also shown that the $4 \mathrm{G} / 5 \mathrm{G}$ polymorphism did not lead to an increased risk of myocardial infarction in young (not more than 45 years) men [38]. Populations of 241 patients and 179 controls were enrolled in that study.

Since the $4 \mathrm{G} / 5 \mathrm{G}$ polymorphism is associated with the $P A I-1$ gene promoter activity under interleukin-1 stimulation [22], it may in-
As mentioned above, the data on possible correlation between the polymorphism and occurrence or progression of cancer are scarce. There were no significant differences in the 4G/5G genotype distributions and allele frequencies between a small population of the advanced ovarian cancer cell lines and peripheral blood lymphocytes of healthy control [39]. It should be noted that in a separate study elevated levels of PAI-1 was found in tumor tissues obtained from patients with advanced ovarian cancer (FIGO IIIc) when compared to those in normal ovarian tissues [40].

Our study implies that it is possible that the $4 \mathrm{G} / 5 \mathrm{G}$ polymorphism of the PAI-1 gene may not be directly involved in the development and/or progression of breast cancer but further research, conducted on larger population, are needed to clarify this point.

The authors thank Dr. J. Pytel of Department of Gynaecological Oncology, Medical University of Łódź and Dr. H. RomanowiczMakowska of Institute of Polish Mother's Memorial Hospital, Łódź (Poland) for providing the breast cancer tissue samples. Technical assistance of D. Piestrzeniewicz is appreciated. 


\section{R E F E R E N C E S}

1. Liotta, L.A., Steeg, P.S. \& Stetler-Stevenson, W.G. (1991) Cancer metastasis and angiogenesis: An imbalance of positive and negative regulation. Cell 64, 327-336.

2. Behrens, J. (1993) The role of cell adhesion molecules in cancer invasion and metastasis. Breast Cancer Res. Treat. 24, 175-184.

3. Danø, K., Andreasen, P.A., Grondahl-Hansen, K., Kristensen, P., Nielsen, L.S. \& Skriver, L. (1985) Plasminogen activators, tissue degradation and cancer. Adv. Cancer Res. 44, 139-266.

4. Mignatti, P. \& Rifkin, D.B. (1993) Biology and biochemistry of proteinases in tumor invasion. Physiol. Rev. 73, 161-195.

5. Andreasen, P.A., Kjøller, L., Christensen, L. \& Duffy, M.J. (1997) The urokinase-type plasminogen activator system in cancer metastasis: A review. Int. J. Cancer 72, 1-22.

6. Kute, T.E., Grondahl-Hansen, J., Shao, S.M., Long, R., Russel, G. \& Brünner, N. (1998) Low cathepsin $\mathrm{D}$ and low plasminogen activator type 1 inhibitor in tumor cytosols defines a group of node negative breast cancer patients with low risk of recurrence. Breast Cancer Res. Treat. 47, 9-16.

7. Ravaioli, A., Bagli, L., Zucchini, A. \& Monti, F. (1998) Prognosis and prediction of response in breast cancer: The current role of the main biological markers. Cell Proliferation 31, 113-126.

8. Janicke, F., Schmitt, M., Pache, L., Ulm, K., Harbeck, N., Hofler, H. \& Graeff, H. (1993) Urokinase plasminogen activator (uPA) and its inhibitor PAI-1 are strong and independent prognostic factors in node-negative breast cancer. Breast Cancer Res. Treat. 24, 195-208.

9. Foekens, J.A., Schmitt, M., van Putten, W.L.J., Peters, H.A., Kramer, M.D., Janicke, F. \& Klijn, J.G.M. (1994) Plasminogen activa- tor inhibitor-1 and prognosis in primary breast cancer. J. Clin. Oncol. 12, 1648-1658.

10. Grondahl-Hansen, J., Christensen, I.J., Rosenquist, C., Brunner, N., Mouridsen, H.T., Danø, K. \& Blichert-Toft, M. (1993) High levels of urokinase-type plasminogen activator and its inhibitor PAI-1 in cytosolic extracts of breast carcinomas are associated with poor prognosis. Cancer Res. 53, 2513-2521.

11. Grondahl-Hansen, J., Hilsenbeck, S.G., Christensen, I.J., Clark, G.M., Osborne, C.K. \& Brunner, N. (1997) Prognostic significance of PAI-1 and uPA in cytosolic extracts obtained from node-positive breast cancer patients. Breast Cancer Res. Treat. 43, 153-163.

12. Andreasen, P.A., Georg, B., Lund, L.R., Riccio, A. \& Stacey, S.N. (1990) Plasminogen activator inhibitors: Hormonally regulated serpins. Mol. Cell. Endocrinol. 68, 1-19.

13. Loskutoff, D.J., Sawdey, M., Keeton, M. \& Scheiderman, J. (1993) Regulation of PAI-1 gene expression in vivo. Thromb. Haemost. 70, 135-137.

14. Henry, M., Chomiki, N., Scarabin, P.Y., Alessi, M.C., Peiretti, F., Arvelier, D., Ferrieres, J., Evans, A., Amouyel, P., Poirer, O., Cambien, F. \& Juhan-Vague, I. (1997) Five frequent polymorphism of the PAI-1 gene. Lack of association between genotypes, PAI activity, and triglyceride levels in a healthy population. Arterioscler. Thromb. Vasc. Biol. 17, 851-858.

15. Mansfield, M.W., Strickland, M.H., Carter, A.M. \& Grant, P.J. (1994) Polymorphism of the plasminogen activator inhibitor-1 gene in type 1 and type 2 diabetes, and in patients with diabetic retinophaty. Thromb. Haemost. 71, 731-736.

16. Dawson, S., Hamsten, A., Wiman, B., Henney, A. \& Humphries, S. (1991) Genetic variation at the plasminogen activator inhibitor-1 locus is associated with altered levels of plasma plasminogen activator inhibitor-1 activity. Arterioscler. Thromb. 11, 183-190. 
17. Klinger, K.W., Winqvist, R., Riccio, A., Andreasen, A.P., Sartorio, R., Nielsen, L.S., Stuart, N., Stanislovitis, P., Watkins, P., Douglas, R., Grzeschik, K.H. \& Alitalo, K. (1991) Plasminogen activator inhibitor type 1 gene is located at region q21.3-q22 of chromosome 7 and genetically linked with cystic fibrosis. Proc. Natl. Acad. Sci. U.S.A. 84, 8548-8552.

18. Dawson, S., Wiman, B., Hamsten, A., Green, F., Humphries, S. \& Henney, A.M. (1993) Two allele sequences of a common polymorphism in the promoter of the plasminogen activator inhibitor-1 (PAI-1) gene respond differently to interleukin-1 in HepG2 cells. J. Biol. Chem. 268, 10739-10745.

19. Henry, M., Tregouet, D.A., Alessi, M.C., Aillaud, M.F., Visviks, S., Siest, G., Tiret, L. \& Juhan-Vague, I. (1998) Metabolic determinants are much more important than genetic polymorphisms in determining the PAI-1 activity and antigen plasma concentrations. A family study with part of the Stanislas Cohort. Arterioscler. Thromb. Vasc. Biol. 18, 84-91.

20.Junker, R., Nabavi, D.G., Wolff, E., Ludermann, P., Nowak-Gottl, U., Kase, M., Baumer, R., Ringelstein, E.B. \& Assmann, G. (1998) Plasminogen activator inhibitor-1 4G/5G-genotype is associated with cerebral sinus thrombosis in factor $\mathrm{V}$ Leiden carries. Thromb. Haemost. 80, 706-707.

21. Margaglione, M., Cappuci, G., Colaizzio, D., Giuliani, N., Vecchione, G., Grandone, E., Pennelli, O. \& Di Minno, G. (1998) The PAI-1 gene locus $4 \mathrm{G} / 5 \mathrm{G}$ polymorphism is associated with a family history of coronary artery disease. Arterioscler. Thromb. Vasc. Biol. 18, $152-156$.

22. Iwai, N., Shimoike, H., Nakamura, Y., Tamaki, S. \& Kinoshita, M. (1998) The 4G/5G polymorphism of the plasminogen activator inhibitor gene is associated with the time course of progression to acute coronary syndromes. Atheriosclerosis 136, 109-114.
23. Smolarz, B., Błasiak, J., Piestrzeniewicz, D. \& Pytel, J. (1998) Plasminogen activator inhibitor-1 (PAI-1) gene 4G/5G promoter polymorphism in subject with cancer. Cell. Mol. Biol. Lett. 3, 49-56.

24. Bloom, H.J.G. \& Richardson, W.W. (1957) Histological grading and prognosis in breast cancer. A study of 1,409 cases of which 359 have been followed for 15 years. Br. J. Cancer 11, 359-377.

25. Scarf, R.W. \& Torloni, H. (1968) Histological typing of breast tumors; Geneva, World Health Organization, pp. 13-20.

26. Falk, G., Almqvist, A., Nordehen, A., Svensson, H. \& Wiman, B. (1995) Allele specific PCR for a detection of a sequence polymorphism in the promoter region of the plasminogen activator inhibitor-1 (PAI-1) gene. Fibrynolysis 9, 170-174.

27. Eriksson, P., Kallin, B., Van't Hooft, F.M., Bavenholm, P. \& Hamsten, A. (1995) Allele specific increase in basal transcription of the plasminogen-activator inhibitor 1 gene is associated with myocardial infarction. Proc. Natl. Acad. Sci. U.S.A. 92, 1851-1855.

28. Mahmoud, R., Raccah, M.C., Alessi, M.C., Aillaud, M.F., Juhan-Vague, I. \& Vague, P. (1992) Fibrinolysis in insulin dependent patients with or without nepropathy. Fibrinolysis 6, 105-109.

29.Juhan-Vague, I., Vague, P.H., Alessi, M.C., Badier, C., Valadier, J., Aillard, M.F. \& Atlan, C. (1987) Relationship between plasma insulin, triglyceride, body mass index, and plasminogen activator inhibitor-1. Diabetes Metab. 13, 331-336.

30. Yang, X.C., Jing, T.Y., Resnick, L.M. \& Phillips, G.B. (1993) Relation of hemostatic risk factors to other risk factors for coronary heart disease and to sex hormone in men. Arterioscler. Thromb. 13, 467-471.

31. Kerins, D.M., Hao, Q. \& Vaughan, D.E. (1995) Angiotensin induction of PAI-1 in endothelial 
cells is mediated by the hexapeptide angiotensin IV. J. Clin. Invest. 96, 2515-2520.

32. Eliasson, B., Attval, S., Taskinen, M.R. \& Smith, U. (1994) The insulin resistance syndrome in smokers is related to smoking habits. Arterioscler. Thromb. 14, 1446-1450.

33. Hendriks, H.F.J., Veenstgra, J., Velthuiste Wierik, E.J.M., Schaafsma, G. \& Kluft, C. (1994) Effect of moderate dose of alcohol with evening meal on fibinolytic factors. Br. Med. J. 308, 1003-1005.

34.Pralong, G., Calandra, T., Glauser, M.P., Schellekens, J., Verhoef, J., Bachmann, F. \& Kruithof, E.K.O. (1989) Plasminogen activator inhibitor 1: A new prognostic marker in septic shock. Thromb. Haemost. 61, 459-462.

35. Ye, S., Green, F.R., Scarabin, P.Y., Nicaus, V., Bara, L., Dawson, S.J., Humphries, S.E., Evans, A., Luc, G., Cambou, J.P., Arvelier, D., Henney, A.M. \& Cambien, F. (1995) The $4 \mathrm{G} / 5 \mathrm{G}$ genetic polymorphism in the promoter of the plasminogen activator inhibitor-1 (PAI-1) gene is associated with differences in plasma PAI-1 activity but not with risk of myocardial infarction in the ECTIM study. Thromb. Haemost. 74, 837-841.

36. Burzotta, F., Di Castelnuovo, A., Amore, C., D’Orazio, A., Di Bitondo, R., Donati, M.B. \& Iacoviello, L. (1998) 4G/5G promoter PAI-1 gene polymorphism is associated with plas- matic PAI-1 activity in Italians: A model of gene-environment interaction. Throm. Haemost. 79, 354-358.

37. Ridker, P.M., Hennekens, C.H., Lindpainter, K., Stampfer, M.J. \& Miletich, J.P. (1997) Arterial and venous thrombosis is not associated with the $4 \mathrm{G} / 5 \mathrm{G}$ polymorphism in the promoter of the plasminogen activator inhibitor gene in a large cohort of US men. Circulation 95, 59-62.

38. Junker, R., Heinrich, J., Schulte, H., Tataru, M., Kohler, E., Schonfeld, R., Nowak-Gottl, U. \& Assmann, G. (1998) Plasminogen activator inhibitor-1 4G/5G-polymorphism and factor $\mathrm{V}$ Q506 mutation are not associated with myocardial infarction in young men. Blood Coag. Fibrinol. 9, 597-602.

39. Türkmen, B., Schmitt, M., Schmalfeldt, B., Trommler, P., Hell, W., Creutzburg, S., Graeff, H. \& Magdolen, V. (1997) Mutational analysis of the genes encoding urokinase-type plasminogen activator (uPA) and its inhibitor PAI-1 in advanced ovarian cancer. Electrophoresis 18, 686-689.

40.Kuhn, W., Pache, L., Schmalfeldt, B., Dettmar, P., Schmitt, M., Janicke, F. \& Graeff, H. (1994) Urokinase (uPA) and PAI-1 predict survival in advanced ovarian cancer patients (FIGO III) after radical and platinum-based chemotherapy. Gynecologic. Oncol. 55, 401409. 